\title{
Physiological Repairing of Postpartum Rat Uterus Treated with Pelawan (Tristaniopsis obovata Benn.) Extract
}

\author{
Yusfiati $^{\mathrm{a}, *}$, W. Manalu ${ }^{\mathrm{b}}$, H. Maheshwari ${ }^{\mathrm{b}}$, \& Andryanto $^{\mathrm{b}}$ \\ ${ }^{a}$ Biology Department, Faculty of Mathematics and Natural Sciences, University of Riau \\ Bina Widya Campus, Subrantas Street 12,5 Km, Panam, Pekanbaru City, Riau Province, Indonesia \\ 'Department of Anatomy, Physiology, and Pharmacology, Faculty of Veterinary Medicine, IPB University \\ Kampus IPB Dramaga, Bogor 16680, West Java, Indonesia \\ ${ }^{*}$ Corresponding author: fiayahya@yahoo.com.au \\ (Received 25-10-2020; Revised 05-03-2021; Accepted 10-03-2021)
}

\begin{abstract}
The study examined the effectiveness of ethyl-acetate fraction of Pelawan extract on the activities of superoxide dismutases in physiological repairing of uterus in postpartum rat based on SOD activity, MDA concentration, and $\mathrm{Cu}, \mathrm{Zn}$ SOD expressions. The experiment was arranged with a factorial, completely randomized design. Seventy-two female rats were divided into 4 groups, namely, control 1 (P01=9), control 2 (P02=9), giving birth once (P1= 27), and giving birth twice (P2= 27). The experimental rats were given treatments orally with 4 doses, namely $0 \mathrm{mg} / \mathrm{kg} \mathrm{BW}, 50 \mathrm{mg} /$ $\mathrm{kg} \mathrm{BW}, 100 \mathrm{mg} / \mathrm{kg} \mathrm{BW}$, and $150 \mathrm{mg} / \mathrm{kg} \mathrm{BW}$. Observation data were taken on days 0,3 , and 5 after parturition. Variables measured were SOD activity, MDA levels, and the number of cells in the uterine tissue expressing $\mathrm{Cu}, \mathrm{Zn}$ SOD. The results of studies on the condition of P01, P02, P1, and P2 showed significant changes in $\mathrm{Cu}, \mathrm{Zn}$ SOD expressions. The low of SOD and MDA activities were found at doses of $100 \mathrm{mg}$ and $150 \mathrm{mg}$. The high number of cells expressing $\mathrm{Cu}, \mathrm{Zn}$ SOD in the epithelium cells and gland cells were found at a dose of $\mathbf{1 0 0} \mathbf{m g}$. Antioxidant plant extracts and their dosages determine the activities of SOD, MDA, and $\mathrm{Cu}, \mathrm{Zn}$ SOD expressions in the uterus that will affect the process of repairing and involution of uterine tissue. Allegedly, the bioactive compounds extracted at certain doses effectively affect the physiological repair of cells in the uterine tissue of postpartum mothers.
\end{abstract}

Keywords: superoxide dismutase; repairing activity; uterus; tristaniopsis

\section{INTRODUCTION}

In mammalian animals, the placentae are expelled and the corpora lutea of pregnancy regress at parturition, resulting in dramatic reductions in plasma concentrations of progesterone and estrogens (Wettermann, 1980). During postpartum, the uterine organ in female mammalian animals and women undergo an involution process. During the involution period, the uterus experiences contractions, autolysis, cell proliferation, and regeneration. An involuting uterus is a temporary barrier to fertility in cows, ewes, and sows (Kiracofe, 1980). In animal agriculture, the longer uterine involution process during postpartum can increase the interval from parturition to conception that eventually decreases productivity. Reproductive efficiency can be increased in farm animals by decreasing the interval from parturition to conception (Wettermann, 1980).

The condition for the restoration of the endometric blood vessels and their cells is determined by the pattern of secretion of estrogen (Flowers et al., 1991). However, the condition of the postpartum uterus undergoes autolysis due to the presence of excess free radicals, which can increase lipid peroxidation. Furthermore, lipid peroxide decomposes into malondialdehyde (MDA) in the blood, and the presence of MDA is used as a marker of cellular damage in tissues (Gumus et al., 2017). The condition of autolysis during parturition causes the decrease of superoxide dismutase (SOD) enzyme and the catalase enzyme in the uterus. Therefore, to improve the involution process of the uterus during postpartum in mammalian animals, it is proposed to use plant extract as a source of antioxidants.

Pelawan (Tristaniopsis obovata Benn.) plant has been used by the people of Talang Mamak tribe in Siak Regency, Riau Province, Indonesia for the treatment of women after giving birth. Pelawan ethanol extract contains flavonoids, alkaloids, tannins, phenols, and steroids (Sartika et al., 2013; Oktari et al., 2014). Ethyl acetate fraction of Tristaniopsis obovata Benn. extract with the DPPH method has a high antioxidant activity value with an $I C_{50}$ value of 28.93, indicating that the extract of T. obovata Benn. can be used for the medication (Yusfiati et al., 2020). Using herbal plants with high antioxidant properties is to prevent the emergence of various diseases that cause death after childbirth complications and 
death after giving birth. Administration of Symplocos racemosa plant extracts and T. obovata Benn ethanol extract in the rat after giving birth accelerate uterine involution (Saraswathi et al., 2012; Ihsan et al., 2016).

The present study was designed to evaluate the effect of T. obovata Benn. extract on the activity of the enzyme superoxide dismutase in the uterus of postpartum mammalian animals by using rats as experimental animals. This study aimed to evaluate the activity of the superoxide dismutase enzyme in the physiological repairing of postpartum rat uterus based on SOD activity, MDA concentration, and $\mathrm{Cu}, \mathrm{Zn}$ SOD expressions in the uterine cells in response to the administration of ethyl acetate fraction of T. obovata Benn. extract. The results of this study can be applied in improving uterine involution in mammalian animals to improve reproduction efficiency and productivities of mammalian animal farmings.

\section{MATERIALS AND METHODS}

\section{Ethyl Acetate Fraction of Tristaniopsis obovata Benn Extract}

A total of $7 \mathrm{~kg}$ of Pelawan leaves were collected and obtained from Sultan Syarif Hasyim Forest Park, Siak Regency, Pekanbaru, Indonesia. Pelawan leaves were taken from stems of 2, 3, and 4 . Cleaned Pelawan leaves were dried in an oven at $40^{\circ} \mathrm{C}$ and crushed into a powder. The Pelawan powder at the weight of $600 \mathrm{~g}$ was mixed with $6 \mathrm{~L} \mathrm{70 \%} \mathrm{ethanol,} \mathrm{then} \mathrm{the} \mathrm{mixture} \mathrm{was} \mathrm{ex-}$ tracted with a rotary vacuum evaporator and dried in an oven at $40^{\circ} \mathrm{C}$ to obtain the initial ethanol extract or crude extract. The crude extract was fractionated using ethyl acetate solvent by using the vacuum liquid chromatography (VLC) method to obtain the ethyl acetate fraction.

\section{Experimental Animals}

Rats were used in this research under ethical approval 113-2018IPB from the LPPM IPB University, Bogor. The experimental rats were raised in the Animal Laboratory Unit of the Faculty of Veterinary Medicine, Bogor, Indonesia. A total of 86 Rattus novergicus Sprague-Dawley rats consisted of 72 female rats aged 50-60 days, and 14 male rats aged 50-60 days were acclimated for 10 days in 24 cages, each with a size of $36 \times 28$ $x 12 \mathrm{~cm}$ given rice husk. The experimental rats were fed with chicken pellets (PUR 512-Bravo). Before treatment, the experimental rats were given antibiotics and worm medicine (Kalibazen $0.2 \mathrm{~mL} / \mathrm{oral}$ ) to eliminate worm infections.

The experiment was designed to evaluate the effects of pelawan extract administration in rats during the first and the second parturition on the MDA concentrations and SOD, Cu, Zn SOD activities in the uterus. The experiment was arranged in a completely randomized design with a $2 \times 4 \times 3$ factorial arrangement. The first factor was the duration of treatment consisted of 2 levels, i.e., one reproduction cycle during the first parturition (7 days before mating and 5 days after the first parturition) and two reproduction cycles during the first and the second parturitions (7 days before mating and 5 days after the first parturition continued with 7 days before mating and 5 days after the second parturition). The second factor was a dose of pelawan extract consisted of 4 levels, i.e., 0, 50, 100, and $150 \mathrm{mg} / \mathrm{kg}$ BW.

The third factor was the time of uterine observation consisted of 3 levels, i.e., 0,3 , and 5 days after parturition. In the experimental rats treated with Pellawan extract for one parturition (P1), the time of uterine observation was conducted on the day of parturition 1 , day 3 of parturition 1 (after 2 days of pelawan extract treatment after parturition 1), and day 5 of parturition 1 (after 4 days of pelawan extract treatment after parturition 1). In the experimental rats treated with Pelawan extract for two parturitions (P2), the time of uterine observation was conducted at the day of parturition 2, day 3 of parturition 2 (after 2 days of pelawan extract treatment after parturition 2), and day 5 of parturition 2 (after 4 days of pelawan extract treatment after parturition 2).

Each experimental unit used 3 rats. Therefore, the total number of female experimental rats used in the study were 72 . All-female experimental rats were mated with the ratio of 1 male rat to mate 3 female rats. Pregnant female rats are known by observing at the vaginal opening area the presence of white vaginal plug. Then, each pregnant female rat was maintained in a separate cage. The pregnancy of female rats lasted for 20-22 days until giving birth.

The female experimental rats from the control group were not given the extract of pelawan extract. The experimental rats treated with pelawan extracted for one reproduction cycle of the first parturition (P1), the pelawan extract at doses of $50 \mathrm{mg} / \mathrm{kg} \mathrm{BW}, 100 \mathrm{mg} /$ $\mathrm{kg} \mathrm{BW}$, and $150 \mathrm{mg} / \mathrm{kg}$ BW were given for 7 days before mating and 5 days after the fist parturition. The experimental rats were treated with pelawan extract for two reproduction cycles of parturition 1 and parturition 2 (P2). The pelawan extracts were administered at doses of $50 \mathrm{mg} / \mathrm{kg}$ body weight, $100 \mathrm{mg} / \mathrm{kg}$ body weight, and $150 \mathrm{mg} / \mathrm{kg}$ bodyweight for 7 days before mating and 5 days after giving birth in the first parturition cycle and continued with the administration of pelawan extract with the same doses 7 days before mating and 5 days after giving birth in the second parturition cycle.

In the experimental rats observed for one cycle of reproduction during parturition 1 , the concentration of MDA, the activity of SOD, and the expression of $\mathrm{Cu}, \mathrm{Zn}$ $\mathrm{SOD}$ in the uterine cells were measured in the uterine tissue of the experimental rats on day 0 (at parturition 1), day 3 after parturition 1, and day 5 after parturition 1. In the experimental rats treated with pelawan extract during two reproduction cycles during parturition 1 and parturition 2, the concentration of MDA, the activity of $\mathrm{SOD}$, and the expression of $\mathrm{Cu}, \mathrm{Zn}$ SOD were measured in the uterine tissue of the experimental rats on the second parturition, i.e., on day 0 (at parturition 2), day 3 after parturition 2, and day 5 after parturition 2. Uterine histology from each treatment was prepared using the paraffin method on day 0 (at parturition 2), day 3 after parturition 2, and day 5 after parturition 2 stained with 
immunohistochemical staining $\mathrm{Cu}, \mathrm{Zn}-\mathrm{SOD}$ avidin-biotin method (Blesson et al., 2012; Quzwain \& Suryawati, 2017; Wresdiyati et al., 2019).

\section{Measurement of MDA Levels}

MDA levels in the uterine tissues were measured at the Molecular and Biochemical Laboratory of Faculty of General Medicine of UI Salemba, Jakarta, Indonesia, using Lipid Peroxidation (MDA) Assay Kit (Colorimetric/ Fluorometric) (Abcam, ab118970). Fresh uterine tissue with the weight of $\pm 0.5 \mathrm{~g}$ was mashed in $1 \mathrm{~mL}$ of phosphate buffer solution ( $\mathrm{pH} 7.4$ ), then centrifuged at $10000 \mathrm{rpm}$ for 20 minutes. A total of $200 \mu \mathrm{L}$ of uterine supernatant in all treatments was added with $200 \mu \mathrm{L}$ of $250 \mathrm{mg}$ TBA solution in $7.5 \mathrm{~mL}$ of glacial acetic acid. Preparation of standard MDA solutions (4.17 M) with volumes of $0,6,12,18,24$, and $30 \mu \mathrm{L}$ were diluted with $\mathrm{ddH}_{2} \mathrm{O}$ volumes of $600,594,588,582,576$, and $570 \mu \mathrm{L}$. The standard MDA produced were $0.4(2 \mu \mathrm{M}), 0.8(4$ $\mu \mathrm{M}), 1.2(6 \mu \mathrm{M}), 1.6(8 \mu \mathrm{M})$, and $2.0(10 \mu \mathrm{M})$. Standard MDA solutions were added with $200 \mu \mathrm{L}$ of TBA $250 \mathrm{mg}$ solution in $7.5 \mathrm{~mL}$ of glacial acetic acid. All solutions were incubated for 60 minutes at $95^{\circ} \mathrm{C}$. After being cooled, the solution was centrifuged at $13000 \mathrm{rpm}$ for 10 minutes. The supernatant in the upper layer was used for measurements of absorbance on a micro-plate reader with $E x / E m=532 / 553 \mathrm{~nm}$ for fluorometric testing. Sample concentrations were obtained by plotting the sample absorbance data into a standard curve (Adyttia et al., 2016).

\section{Measurement of SOD Activity}

Measurement of SOD activity was carried out at the Microbiology Laboratory, Primate Study Center, IPB University, Bogor, Indonesia. A total of 2 uterine tissue samples from experimental rats treated with the Pelawan extracts having the highest antioxidant value and control were measured by uterine SOD with the uterine SOD ELISA Kit (Abcam, ab65354) (Han et al., 2020). Fresh uterine tissue at the weight of $\pm 0.5 \mathrm{~g}$ was mashed and put into $1 \mathrm{~mL}$ a phosphate buffer solution of $\mathrm{pH} \mathrm{7.4,} \mathrm{and} \mathrm{then} \mathrm{the} \mathrm{solution} \mathrm{was} \mathrm{centrifuged} \mathrm{at}$ $10000 \mathrm{rpm}$ for 20 minutes. Preparation of wells set was blank $1=20 \mu \mathrm{L}$ ddH2O, blank $2=20 \mu \mathrm{L}$ sample, blank $3=$ $20 \mu \mathrm{L}$ ddH2O, and wells sample $=20 \mu \mathrm{L}$. Then, each well was added with a $200 \mu \mathrm{L}$ working WTS solution, another $20 \mu \mathrm{L}$ buffer dilution solution was added to blank 2 and blank 3. Enzyme Working solution at a volume of $20 \mathrm{~mL}$ was added to each sample well and blank 1, mixed, and incubated at $37^{\circ} \mathrm{C}$ for 20 minutes. Then, the output (OD450 nm) was measured with a microplate reader. The results of measurement data output were calculated SOD activity and \% of the average resistance with the following formula:

$\%$ Inhibition rate $=\left\{\left[\left(\mathrm{A}_{\text {blank1 } 1}-\mathrm{A}_{\text {blank } 3}\right)-\left(\mathrm{A}_{\text {sample }}-\mathrm{A}_{\text {blank } 2}\right)\right] /\right.$ $\left.\left(\mathrm{A}_{\text {blank } 1}-\mathrm{A}_{\text {blank } 3}\right)\right\} \times 100 \%$

SOD Activity (unit $/ \mathrm{mL})=$

[\%Average resistance $\left.\times 1 \frac{\mathrm{unit}}{10 \mu \mathrm{L}}\right] / 50 \%$ where A was absorbance and 50\% was SOD activity unit is defined as the amount of SOD needed to cause $50 \%$ inhibition of working-enzyme oxidation $\left(\mathrm{SOD}_{50}\right)$.

\section{Immunohistochemistry of $\mathrm{Cu}, \mathrm{Zn}$ SOD in the Uterus}

Detection of $\mathrm{Cu}, \mathrm{Zn} \mathrm{SOD}$ in the uterus was conducted by immunohistochemical staining of $\mathrm{Cu}, \mathrm{Zn}$ SOD. Immunohistochemical staining was conducted by using Abcam Anti Superoxide Dismutase 1 antibody (Abcam, ab51254) with a slight modification in the type of secondary antibody. The two uterine tissues in each treatment and control were fixed with BNF 10\% for 72 hours, then dehydrated with multi levels alcohol, cleared with xylol, and embedded with paraffin (histoplast $58^{\circ} \mathrm{C}$ ). Paraffin blocks were cut as thick as $5 \mu \mathrm{m}$. The preparations were deparaffinized and rehydrated, and then immunohistochemical staining was carried out on $\mathrm{Cu}, \mathrm{Zn}$ SOD.

Immunohistochemical staining of $\mathrm{Cu}, \mathrm{Zn}$ SOD by the avidin-biotin method was conducted with the following steps. The preparations of uterine tissue were deparaffinized with xylol and rehydrated with multi-levels of alcohol, aquadest, and MiliQ. Removal of endogenous peroxidase enzymes was conducted by the addition of hydrogen peroxidase $\left(\mathrm{H}_{2} \mathrm{O}_{2} 10 \%\right)$ and left for 30 minutes at $37^{\circ} \mathrm{C}$, and then the preparation was washed with PBS at $\mathrm{pH}$. 7.4. Then, the preparation was dropped with $10 \%$ Sniper background normal serum for 30 minutes to block nonspecific bonds and subsequently washed with PBS. Then, the preparation was unmasked with the addition of $0.2 \%$ AgTripsin in $\mathrm{CaCl}_{2}$, and the preparation was washed with PBS. Subsequently, the preparate was given a primary antibody, namely Abcam Anti Superoxide Dismutase 1 antibody (Abcam, ab51254) at $4^{\circ} \mathrm{C}$, incubated for 1 night (1 x 24 hours). Then the preparate was washed with PBS, then pieces of tissue were incubated with Linked Reagent Biotinylated for 30 minutes at $37^{\circ} \mathrm{C}$, and then the preparate was washed again with PBS, incubated again with Streptavidin HRP for 30 minutes at $37^{\circ} \mathrm{C}$, and then washed with PBS. Then, the tissue pieces were given a Diethyl Amino Benzyn (DAB) substrate for 50 seconds and washed with MiliQ. The preparations were countered with hematoxylin, dehydrated, cleared, and mounted (Wresdiyati et al., 2019). The positive control used white rat mammary gland tissue that was stained with the immunohistochemical staining used in this protein. SOD in the tissue was observed with a light microscope. Observation of cells in the uterine tissue was conducted with two types of observations, i.e., qualitative and quantitative observations. Qualitative observation of a positive reaction product in the cells of the uterine tissue was conducted by comparing the brown color that was formed and its distribution in all parts of the tissue. The brown color reflected the content of $\mathrm{Cu}$, $\mathrm{Zn}$ SOD. Quantitative observation of cells in the uterine tissue that reacted positively at the level of $\mathrm{Cu}, \mathrm{Zn}$ SOD content. The calculation of these cells was conducted every 10 times the field of view at $400 \times$ magnification. 


\section{Data Analysis}

The results of measurement consisted of two types of data, i.e., qualitative and quantitative data. Quantitative data on MDA and SOD concentrations and the number of cells stained with IHC Cu, Zn SOD were calculated using the Image J program. All data were analyzed by one-way ANOVA test and T-test $(\mathrm{p}<0.05)$ SPSS 23 program in both parent groups after giving birth once and twice on days 0,3 , and 5 .

\section{RESULTS}

Treatment with pelawan leave extract significantly affected $(p<0.05)$ the SOD activities in the uterine organs of female rats after giving birth once and twice. The SOD activities in the uterus significantly decreased in the experimental rats treated with Pelawan leaves ethyl acetate fraction extract at doses of 50 and $100 \mathrm{mg} / \mathrm{kg} \mathrm{BW}$ (Table 1). The decrease in SOD activities in the uterus was observed in experimental rats both giving birth once and twice. However, there were no significant effects of the frequency of giving birth and days of uterine observations on the SOD activities in the uterus. Even though there was a significant decrease in SOD activities in the uterus of experimental rats treated with pelawan extract at doses of 50 and $100 \mathrm{mg} / \mathrm{kg} \mathrm{BW}$, there were no significant interaction effects of the dose of pelawan extract, the frequency of giving birth, and days of observation on the SOD activities in the uterus. The negative SOD activities were found in experimental rats treated with pelawan extract at doses of 50 and $100 \mathrm{mg} / \mathrm{kg} \mathrm{BW}$, both in the rats giving birth once and twice. However, experimental rats treated with pelawan extract at a dose of $50 \mathrm{mg} / \mathrm{kg}$ BW having a negative SOD activity at the first parturition, the SOD activity increased and reached the highest level $(268.03 \mathrm{U} / \mathrm{mL}) 5$ days after parturition 1 , while experimental rats treated with pelawan extract at a dose of $100 \mathrm{mg} / \mathrm{kg}$ BW still have negative SOD activity in the uterus $(-75.73 \mathrm{U} / \mathrm{mL})$. Both experimental rats treated with pelawan extracts at doses of 50 and $100 \mathrm{mg} /$ $\mathrm{kg}$ BW had positive SOD activities in the uterus 5 days post parturition 2, reaching 148.49 and $148.48 \mathrm{U} / \mathrm{mL}$, respectively. Control experimental rats treated with pelawan extract at a dose of $0 \mathrm{mg} / \mathrm{kg} \mathrm{BW}$ and experimental rats treated with pelawan extract at a dose of $150 \mathrm{mg} / \mathrm{kg}$ BW had positive SOD activities in the uterus at observations on the days of parturitions 1 and 2 continued on 3 and 5 days after parturitions 1 and 2. The experimental rats treated with pelawan extract at a dose of $50 \mathrm{mg}$ reached the highest SOD activity $(268.03 \mathrm{U} / \mathrm{mL}) 5$ days after parturition 1 than all treatments.

Malondialdehyde (MDA) concentrations in the uterus were significantly affected by the giving birth frequency (giving birth once or parturition 1 and giving birth twice parturition 1 and parturition $2(\mathrm{p}<0.01)$. However, there was a significant interaction effect of doses of pelawan extract treatment and stage of observation at parturition 1 and parturition 2 . The dose of pelawan extract, days of observations of the uterus, and their interaction were not significantly different. The MDA concentrations in the uterus after parturition decreased

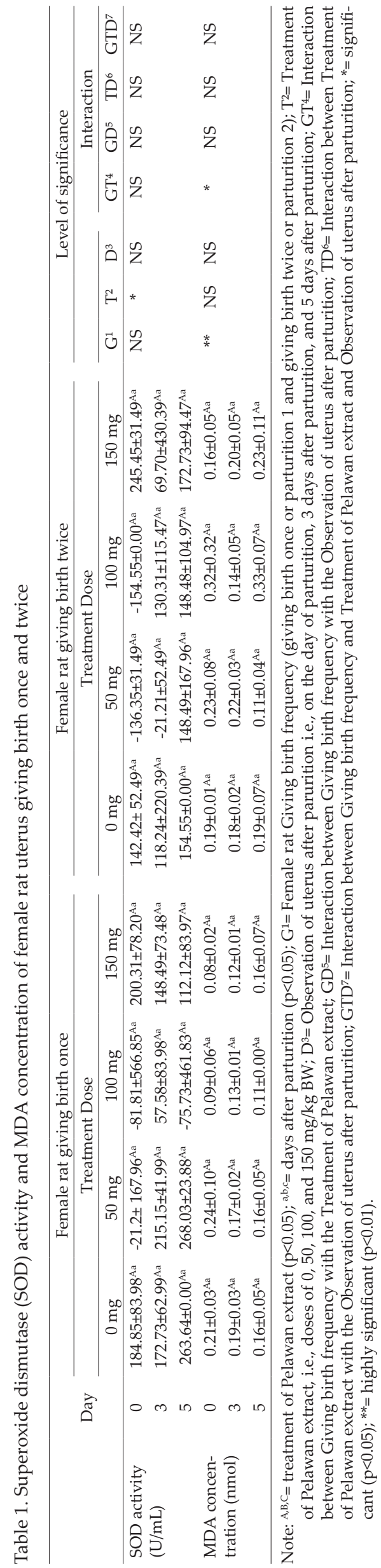


in female rats giving birth once and going up in giving birth twice (Table 1) and statistically significantly different $(p<0.05)$. The extract dose of $100 \mathrm{mg}$ has a high decrease in MDA compared to other doses of treatment in the maternal rats giving birth once, and the highest increase was found in the maternal rats giving birth twice. In all treatments, the concentration of MDA decreased on the $3^{\text {rd }}$ day after parturition and increased again on the $5^{\text {th }}$ day. The decreased and increased concentrations of MDA reflect the health condition of the maternal rats after giving birth.

The number of uterine epithelium cells expressed $\mathrm{Cu}, \mathrm{Zn}$ SOD in maternal rats giving birth once and twice decreased on the $3^{\text {rd }}$ day and did not rise again on the $5^{\text {th }}$ day and based on statistical analysis, and the concentrations were significantly different $(p<0.05)$ (Figure 1A; Figure 1B). The number of uterine epithelium cells in the maternal rats giving birth once treated with pelawan extract at a dose of $150 \mathrm{mg} / \mathrm{kg}$ BW and the maternal control rats giving birth twice expressed $\mathrm{Cu}$, $\mathrm{Zn}$ SOD at the lowest level. The number of epithelium cells in the maternal rats giving birth twice treated with pelawan extract at a dose of $100 \mathrm{mg} / \mathrm{kg}$ BW expressed $\mathrm{Cu}, \mathrm{Zn} \mathrm{SOD}$ at the highest level. The number of uterine epithelium cells expressing $\mathrm{Cu}, \mathrm{Zn}$ SOD in the maternal rats giving birth twice was higher than the maternal rats giving birth once.

The number of uterine gland cells expressing $\mathrm{Cu}$, $\mathrm{Zn}$ SOD in maternal rats giving birth once and twice increased with the increasing days after giving birth $(\mathrm{p}<0.05)$ (Figure 2A; Figure 2B). The number of uterine gland cells expressing $\mathrm{Cu}, \mathrm{Zn}$ SOD was high in the maternal rats treated with pelawan extract at a dose of $100 \mathrm{mg}$. The number of gland cells in the maternal rats giving birth twice and treated with the pelawan extract at a dose of $100 \mathrm{mg} / \mathrm{kg}$ BW expressed $\mathrm{Cu}, \mathrm{Zn} \mathrm{SOD}$ at the highest levels. The lowest number of uterine gland cells expressing $\mathrm{Cu}, \mathrm{Zn} \mathrm{SOD}$ was found in the maternal rats giving birth once treated with pelawan extract at doses of 50 and $150 \mathrm{mg} / \mathrm{kg} \mathrm{BW}$.
The number of uterine stroma cells expressing $\mathrm{Cu}$, $\mathrm{Zn}$ SOD in the maternal rats giving birth twice was higher than in those giving birth once. The numbers of uterine stromal cells expressing $\mathrm{Cu}, \mathrm{Zn}$ SOD in the maternal rats giving birth once and twice increased on the $3^{\text {rd }}$ day and decreased on the $5^{\text {th }}$ day $(p<0.05)$ (Figure 3A; Figure 3B). The high number of uterine stromal cells expressing $\mathrm{Cu}, \mathrm{Zn}$ SOD was found in maternal rats giving birth twice treated with pelawan extract at a dose of $150 \mathrm{mg} / \mathrm{kg}$ BW.

\section{DISCUSSION}

The dose of $100 \mathrm{mg}$ can improve postpartum uterine conditions. Also, a dose of $150 \mathrm{mg}$ can improve postpartum uterine performance in rats giving birth twice. Allegedly, high antioxidant content can affect SOD activity, MDA concentration, and expression of $\mathrm{Cu}, \mathrm{Zn}$ SOD in the uterus tissue. The decreased SOD enzyme activity (Table 1) with the increasing days after giving birth indicates the presence of high free radicals in the uterine tissue. Malondialdehyde (MDA) levels on the first day after giving birth (Table 1) are higher and decrease on the $3^{\text {rd }}$ day and increase again on the $5^{\text {th }}$ day after giving birth. SOD enzyme activities in the maternal rats treated with pelawan extract at a dose of $50 \mathrm{mg} /$ $\mathrm{kg}$ BW were high, and it was suspected that there was a great number of inflammations in the uterine tissue. Meanwhile, treatment of maternal rats with pelawan extract at a dose of $100 \mathrm{mg} / \mathrm{kg}$ BW showed low SOD activities. These results could be related to the condition that the concentration of certain antioxidants in an extract can reduce inflammation in the uterine tissues. The uterine of rats given the toxic substances inflame the high levels of SOD enzyme activities, and treatment with ethanol extract of Ficus vagelli containing nutritious antioxidants can reduce SOD in the uterus (Uchewa \& Ezugworie, 2018). The results of a similar study show that the oral administration of pesticide compounds such as cypermethrin to mice reduces $17 \beta$-estradiol lev-
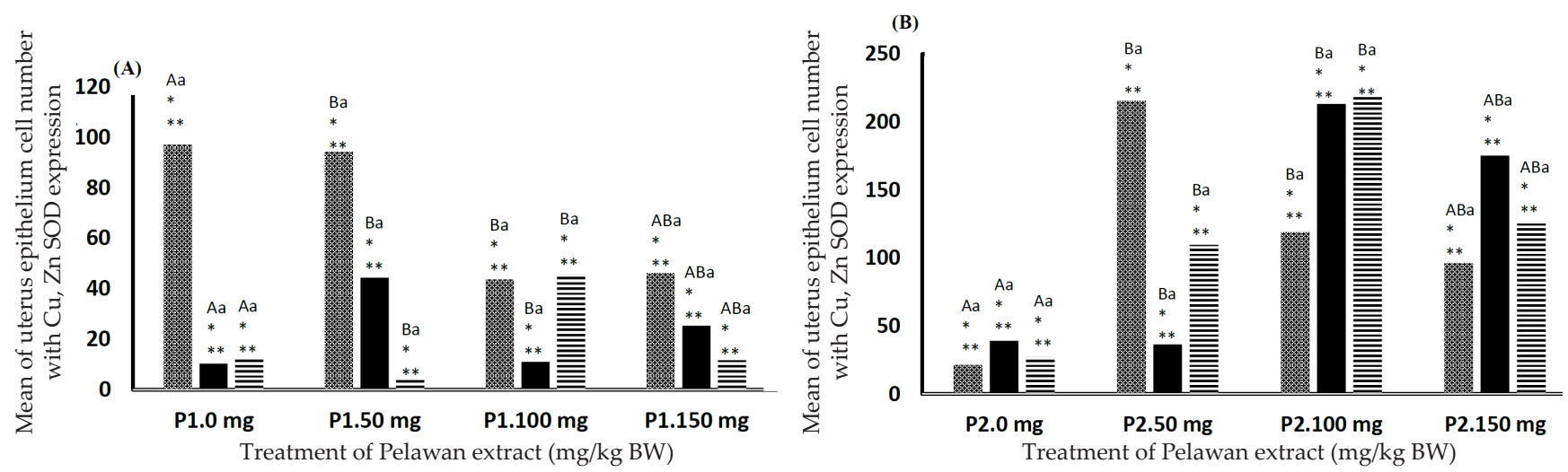

Figure 1. Bar chart of number mean of epithelium cells expressed with $\mathrm{Zn}, \mathrm{Cu} \mathrm{SOD}$ of the female rat uterus after giving birth once (A) and twice (B) on (婎) 0 day, ( $\mathbf{\square}) 3$ days, and (三) 5 days after parturition.

$\mathrm{P} 1=$ The female rats giving birth once; $\mathrm{P} 2=$ The female rats giving birth twice; ${ }^{\mathrm{A}, \mathrm{B}, \mathrm{C}} \mathrm{p}<0.05=$ treatment of Pelawan extract; $;$, $\mathrm{b}, \mathrm{c}$ $\mathrm{p}<0.05=$ days after parturition; ${ }^{*} \mathrm{p}<0.05=\mathrm{vs}$. between giving birth with treatment and days after parturition; ${ }^{* *} \mathrm{p}<0.01=\mathrm{vs}$. female rat giving birth, vs.treatment of Pelawan extract, vs. days after parturition; vs. between giving birth with treatment of Pelawan extract, vs. between giving birth with days after parturition, vs. between treatment of Pelawan exctract with days after parturition. 

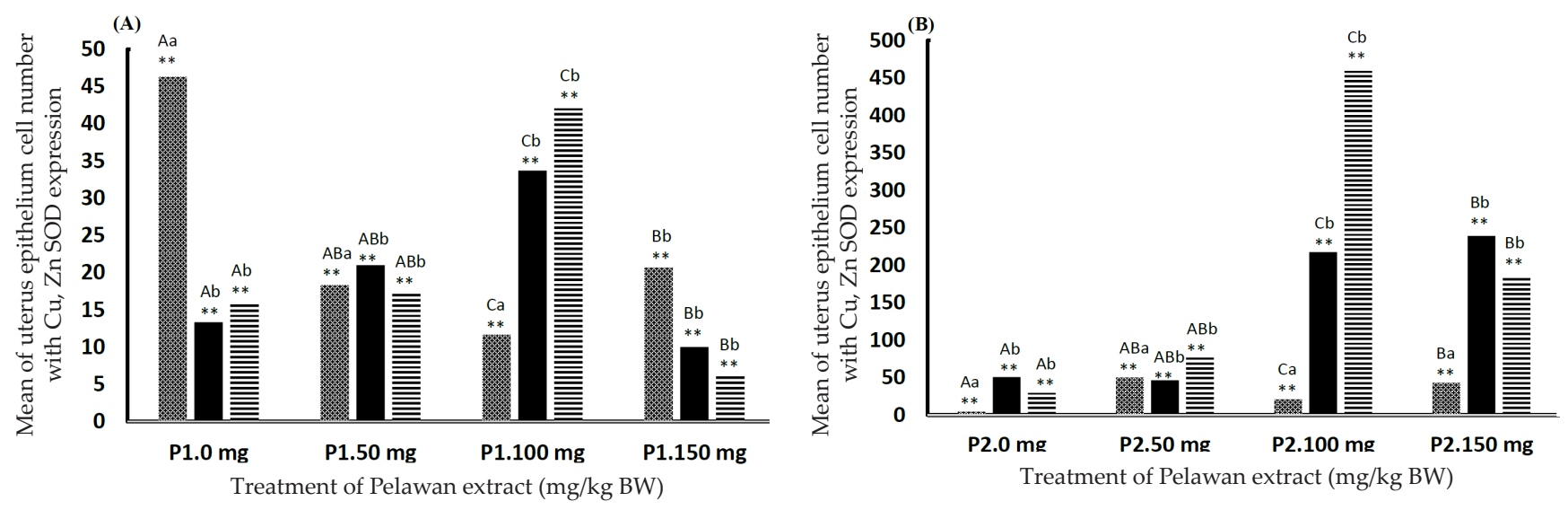

Figure 2. Bar chart of number mean of gland cells expressed with $\mathrm{Zn}, \mathrm{Cu} \mathrm{SOD}$ of the female rat uterus after giving birth once (A) and twice (B) on ( 0 day, ( $\mathbf{\square}) 3$ days, and (三) 5 days after parturition.

$\mathrm{P} 1=$ The female rats giving birth once; $\mathrm{P} 2=$ The female rats giving birth twice; ${ }^{\mathrm{A}, \mathrm{B}, \mathrm{C}} \mathrm{p}<0.05=$ treatment of Pelawan extract; ${ }^{\mathrm{a}, \mathrm{b}, \mathrm{c}}$ $\mathrm{p}<0.05=$ days after parturition; ${ }^{*} \mathrm{p}<0.05=\mathrm{vs}$. between giving birth with treatment and days after parturition; ${ }^{* *} \mathrm{p}<0.01=\mathrm{vs}$. female rat giving birth, vs.treatment of Pelawan extract, vs. days after parturition; vs. between giving birth with treatment of Pelawan extract, vs. between giving birth with days after parturition, vs. between treatment of Pelawan exctract with days after parturition.
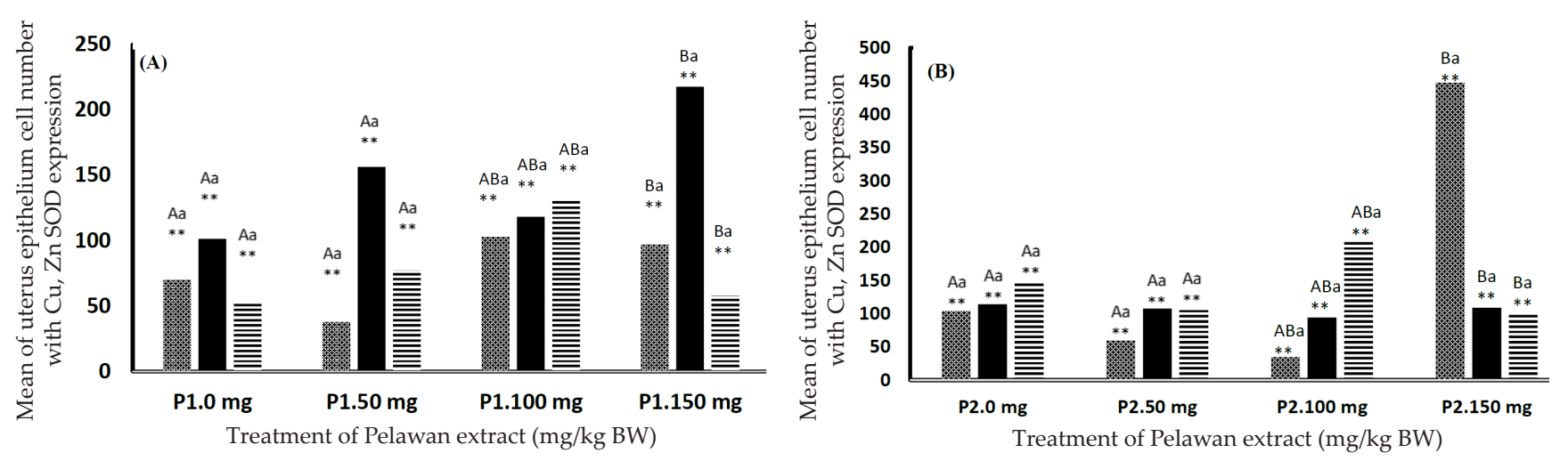

Figure 3. Bar chart of number mean of stroma cells expressed with $\mathrm{Zn}, \mathrm{Cu} \mathrm{SOD}$ of the female rat uterus after giving birth once (A) and twice (B) on ( 0 day, $(\mathbf{\square}) 3$ days, and (三) 5 days after parturition.

$\mathrm{P} 1=$ The female rats giving birth once; $\mathrm{P} 2=$ The female rats giving birth twice; ${ }^{\mathrm{A}, \mathrm{B}, \mathrm{C}} \mathrm{p}<0.05=$ treatment of Pelawan extract; ${ }^{\mathrm{a}, \mathrm{b}, \mathrm{c}}$ $\mathrm{p}<0.05=$ days after parturition; ${ }^{*} \mathrm{p}<0.05=\mathrm{vs}$. between giving birth with treatment and days after parturition; ${ }^{* *} \mathrm{p}<0.01=\mathrm{vs}$. female rat giving birth, vs.treatment of Pelawan extract, vs. days after parturition; vs. between giving birth with treatment of Pelawan extract, vs. between giving birth with days after parturition, vs. between treatment of Pelawan exctract with days after parturition.

els in the blood and increases MDA levels in the uterine tissue (Widowati et al., 2018).

The increasing concentration of lipid peroxide in the tissues shows that the existing endogenous SOD cannot neutralize the excessive free radicals present in the tissues (Sharma et al., 2012). In the present study, the administration of Pelawan extracts at a dose of $50 \mathrm{mg} /$ $\mathrm{kg}$ BW could not reduce free radicals. On the contrary, a dose of $100 \mathrm{mg} / \mathrm{kg}$ BW significantly reduced the presence of free radicals in the tissue. The content of alkaloids having an unstable chemical structure in the extract can affect the instability of the antioxidant bonds to free radicals. Therefore, the antioxidants present in the extract do not function normally to reduce free radicals and eventually increase MDA concentration in the tissue. Conversely, alkaloid content whose chemical structure is stable can bind to free radicals and can reduce MDA (Tse et al., 1991). The role of b-carboline alkaloids in plant extracts with certain concentrations can effectively reduce free radicals in the tissues. The alkaloid extract of b-carboline is effective in reducing free radicals in cell lines at a concentration of $150 \mu \mathrm{g} /$ $\mathrm{mL}$ (Moura et al., 2007). The b-carboline content in the alkaloids showing a significant effect on the antioxidant capacity of certain concentrations has warded off free radicals.

The flavonoid content in the extract can reduce the production of free radicals and can also increase endogenous antioxidants (Kasote et al., 2015). The flavonoid content in the Pelawan ethyl acetate fraction extract may reduce the production of free radicals in the uterus tissue. Flavonoid compounds are polyphenols whose potential as antioxidants depends on their concentrations in the bloodstream after absorption in the 
digestive tract and modification results during metabolism. Polyphenolic compounds determine conjugation reactions with methyl, sulfate, or glucuronide groups and the number of their metabolites formed by the microflora in the large intestine. Flavonoids also can act as signaling molecules in the cells through protein kinase and lipid kinase signaling pathways. Katuk leaf extract (Sauropus androgynous L. Merr), which contains flavonoid compounds, can reduce inflammation in the body of mice by the administration of the extract at a dose of $400 \mathrm{mg} / \mathrm{kg}$ BW (Desnita et al., 2018). In addition, blood MDA concentrations in the rats decreased, and SOD levels increased after administration of Gaharu leaf extract for 10 weeks with doses of $50 \mathrm{mg} / \mathrm{kg} \mathrm{BW}, 100 \mathrm{mg} /$ $\mathrm{kg} \mathrm{BW}$, and $200 \mathrm{mg} / \mathrm{kg}$ BW (Parwata et al., 2016). Water extract of Gaharu leaf contains flavonoid compounds that can function as exogenous antioxidants. The extent of the therapeutic effect of exogenous antioxidants derived from plant extracts depends on the absorption of antioxidants in the digestive tract, distribution, metabolism, and previous storage and secretion. Each plant has therapeutic properties with different doses (Kasote et al., 2015).

The flavonoid content in the Pelawan ethyl acetate fraction extract may have phytoestrogenic activity. Phytoestrogens have a function similar to that of endogenous estrogens. The chemical structure of phytoestrogens is similar to the chemical structure of 17 $\beta$-estradiol (Viggiani et al., 2019). According to Kostelac et al. (2003), phytoestrogens that bind to alpha and beta estrogen receptors can increase the binding of estrogen receptors with estogen-receptor element (ERE). Phytoestrogens are higher in activating beta estrogen receptor binding with ERE than with alpha receptors. 17- $\beta$ Estradiol with a concentration of $0.03 \mu \mathrm{M}$ effectively binds to alpha receptors, and a concentration of 0.01 $\mu \mathrm{M}$ effectively binds to beta receptors. Phytoestrogens
(Genestin compounds) with a concentration of $15 \mu \mathrm{M}$ were effective in activating alpha receptor bonds with ERE and $0.03 \mu \mathrm{M}$ concentrations of beta-receptor bonds with ERE. Phytoestrogens (Genestin compounds) are effective in activating ER-beta bonds with ERE. In contrast, the endogenous hormone (17 $\beta$-estradiol) is less effective at activating the ER-beta bond with ERE. The result of the metabolite daidzein (a phytoestrogen compound), namely equol, activates the RE alpha bond with ERE up to 85 times more effectively. According to Jefferson et al. (2012), the mechanism of action of phytoestrogens against the alpha estrogen receptor and the beta estrogen receptor classically is largely mediated by its hormone feedback action. The affinities of ER alpha and ER beta are relatively weak against phytoestrogens compared to endogenous estradiol. ER activity can be an agonist or antagonistic depending on the presence of estradiol.

The expressions of $\mathrm{Cu}, \mathrm{Zn}$ SOD after administration of ethyl acetate fraction of T. obovata Benn. to female rats giving birth once and twice showed that in the epithelium layer of the endometrium on the third day after giving birth, the expression of $\mathrm{Cu}, \mathrm{Zn}$ SOD decreased and increased again on the fifth day after parturition. Therefore, the uterine glands on the maternal rats on the third and fifth days after giving birth have an increased expression of $\mathrm{Cu}, \mathrm{Zn}$ SOD. The expression of $\mathrm{Cu}, \mathrm{Zn}$ SOD increased in the area of endometrial stromal on the third and the fifth days (Figures 2, 3, and 4). The flavonoid content of Pelawan leaf extract may influence the expression of $\mathrm{Cu}, \mathrm{Zn} \mathrm{SOD}$ in the uterus tissue. The $\mathrm{Cu}$, $\mathrm{Zn}$ SOD content in the plant organs has different levels (Qu et al., 2010). The Cu, Zn SOD gene was expressed in the leaves, stems, and underground stem. The expression of the $\mathrm{Cu}, \mathrm{Zn}$ SOD gene was more expressed in the leaves and stems than in the underground stem.
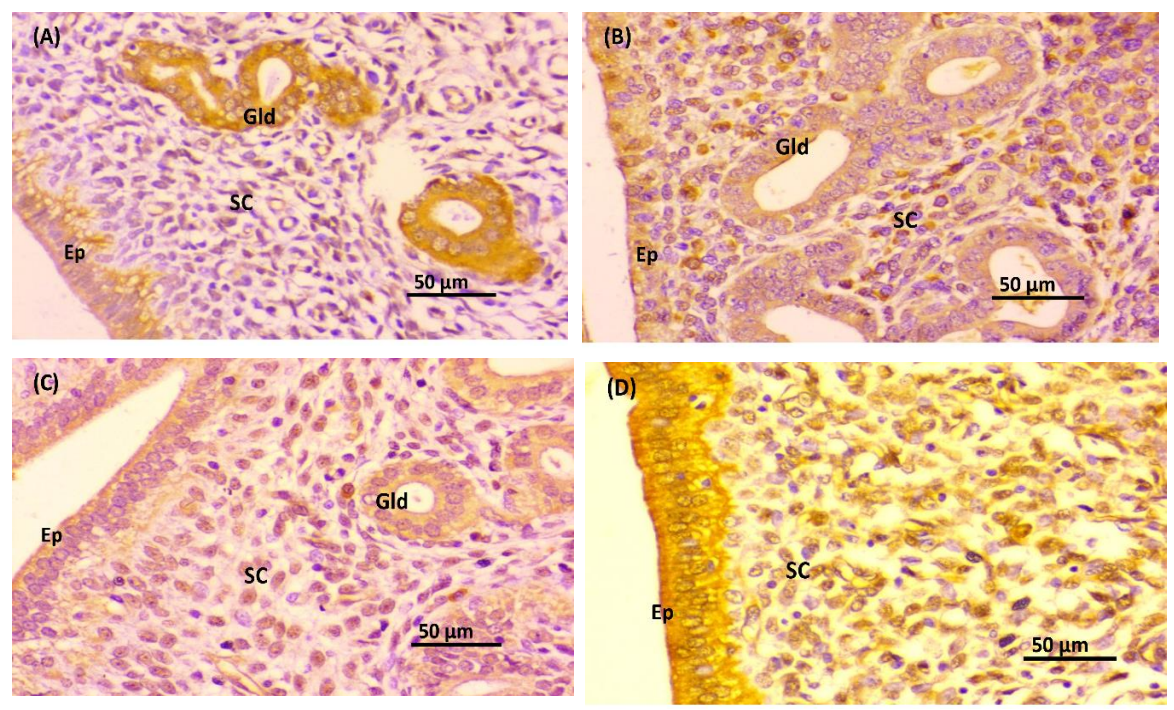

Figure 4. Tissue cells in the uterus stained with IHC Cu, Zn SOD. (A). Dose of $50 \mathrm{mg}$ giving birth twice 5 days after parturition. (B). The dose of $50 \mathrm{mg}$ giving birth once 3 days after parturition. (C). Doses of $100 \mathrm{mg}$ giving birth once 5 days after parturition. (D). The $150 \mathrm{mg}$ dose giving birth twice 5 days after parturition. Ep= Epithelium, Gld= Gland, SC= Stroma Cell. 
The expression of $\mathrm{Cu}, \mathrm{Zn}$ SOD in the uterine tissue shows a promoter bond with the ERE in the plasmid. The potential mechanism of $\mathrm{Cu}, \mathrm{Zn}$ SOD can increase the expression of genes that mediate estrogen receptor $\alpha$ $(\mathrm{ER} \alpha)$ in two ways: first, it directly influences transcription through interactions of $\mathrm{Cu}, \mathrm{Zn}$ SOD with estrogen receptor $\alpha(\mathrm{ER} \alpha)$ and becomes a receptor-DNA complex and the second, indirectly protect protein cell nuclei from oxidation damage. The presence of oxidation will reduce the ability of ER $\alpha$ to bind DNA-containing ERE (Hayashi et al., 1997). The increased expression of $\mathrm{Cu}, \mathrm{Zn}$ SOD in the cells of uterine tissue in the present study showed an increase in the binding of DNAcontaining ERE. The redox, such as Egr1 (Early Growth Response-1), AP1 (Activating Protein 1), NF- $\kappa$ B (Nuclear Factor-kappa B), and Nrf2, affect the regulation of $\mathrm{Cu}$, $\mathrm{Zn}$ SOD expression on performance at the transcriptional level that will change the $\mathrm{Cu}, \mathrm{Zn}$ SOD mRNA for the formation of $\mathrm{Cu}, \mathrm{Zn}$ SOD protein. Therefore, an altered level of $\mathrm{O}_{2}$ in the cell will affect downstream cell signaling targets and affect cell sensitivity and proliferation (Todorovic et al., 2019).

An increase in $\mathrm{Cu}, \mathrm{Zn} \mathrm{SOD}$ in the mammary gland tissue in rats, increases the concentration of estrogen in the blood (Griess et al., 2017). As a result, the concentration of estrogen in the blood will increase. Postmenopausal mothers who were given estrogen hormone therapy experienced an increase in the activity of $\mathrm{Cu}, \mathrm{Zn}$ SOD enzymes in the blood $(47.1 \pm 5.3 \mathrm{U} / \mathrm{mg} \mathrm{Hb})$ compared to postmenopausal mothers without hormone therapy (32.1 $\pm 3.2 \mathrm{U} / \mathrm{mg} \mathrm{Hb}$ ) (Unfer et al., 2014). Estrogen can directly stimulate the activity of $\mathrm{Cu}, \mathrm{Zn}$ SOD in the erythrocytes at a certain dose. In the gene promoter, there is an estrogen receptor area that binds to $\mathrm{Cu}, \mathrm{Zn}$ SOD. The production of $\mathrm{Cu}, \mathrm{Zn} \mathrm{SOD}$ in the blood can be increased by administering serum $17 \beta$-estradiol in menopausal women. 17 $\beta$-estradiol in the blood can stimulate the activity of $\mathrm{Cu}, \mathrm{Zn}$ SOD in the nucleus at promoter nucleus of blood cells to produce estrogen (Unfer et al., 2013; Unfer et al., 2014). In cultured uterine stromal cells treated with estrogen, the expression of $\mathrm{Cu}$ and $\mathrm{Zn}$ SOD increased in the uterine stromal cells (Sugino et al., 2002). The expression of $\mathrm{Cu}, \mathrm{Zn}$ SOD in the uterine tissue cells decreased due to an increase in free radicals in the uterine stroma and an increase in the concentration of PGF2 $\alpha$ (Prostaglandin F2 $\alpha$ ) in the uterus. These free radicals will stimulate MMP (Matrix Metalloproteinase) activity. MMP is an enzyme that can degrade all types of extracellular matrix proteins. PGF $2 \alpha$ played an important role in the contraction and relaxation of smooth muscle in the uterus. The activity and expression of $\mathrm{Cu}, \mathrm{Zn} \mathrm{SOD}$ in the endometrium of the uterus will result in oxidative damage.

Aging in the parent will also reduce $\mathrm{Cu}, \mathrm{Zn}$ SOD in the cytosol and will reduce the production of the estrogen hormone in the parent (Kusunoki et al., 2006). $\mathrm{Cu}, \mathrm{Zn} \mathrm{SOD}$ is highly expressed in the cytoplasm. However, the rat hepatocytes were identified to contain $\mathrm{Cu}, \mathrm{Zn}$ SOD in the nucleus, lysosomes, and mitochondria. $\mathrm{Cu}, \mathrm{Zn}$ SOD in the cytosol is in the nucleotide chain at the promoter of mRNA, and this region is the site of the binding of estrogen $\alpha$ receptors with $\mathrm{Cu}, \mathrm{Zn}$ SOD (Pamela et al., 2011). The gene promoter of human $\mathrm{Cu}, \mathrm{Zn}$ SOD identified an antioxidant responsive element that was located between -356 and -330 from the transcription start of the 3' UTR site (AATAAA and ATTAAA) (Dreger et al., 2010).

The mechanism of superoxide disproportionation in binding radicals in the body is copper ${ }^{2+}$ superoxide anion donating electrons to molecular oxygen by binding to $\mathrm{O}_{2}{ }^{-}$- and the substrate binds to copper ${ }^{2+}$. Reduction of copper ${ }^{2+}$ to copper ${ }^{1+}$ breaks the bond between copper and histidine, and the histidine becomes protonated. These protons donate together with electrons from copper ${ }^{1+}$ to the second $\mathrm{O}_{2}{ }^{--}$anion, forming $\mathrm{H}_{2} \mathrm{O}_{2}$ (Sheng et al., 2014; Griess et al., 2017). However, the excess of $\mathrm{Cu}, \mathrm{Zn}$ SOD exogenous in the body will be pro-oxidants because there is recent evidence to explain that the oxidation of $\mathrm{Cu}^{+}$-SOD1 by peroxy carbonate is more than 100 times faster than the oxidation of $\mathrm{Cu}^{+}$ -SOD1 by $\mathrm{H}_{2} \mathrm{O}_{2}$. Oxidation of the bicarbonate bond with $\mathrm{Cu}^{+}$-SOD1 from $\mathrm{HO} 2$ which occurs to become peroxy carbonate $\left(\mathrm{CO}_{4}^{2-}\right)$. Furthermore, peroxy carbonate is reduced to radicals carbonate $\left(\mathrm{CO}_{3}^{-}{ }^{-}\right)$, which is bound to enzymes so that the enzyme becomes inactivated. This condition results in the $\mathrm{Cu}, \mathrm{Zn}$ SOD enzymes becoming pro-oxidants (Sheng et al., 2014).

The results obtained in the present study have a great potential to be used in improving uterine involution in the postpartum mammalian animals that produce a shorter interval from parturition to conception. In the mammalian animal industry, reproductive efficiency and productivity can be increased by decreasing the interval from parturition to conception (Wettemann, 1980).

\section{CONCLUSION}

The administration of T. obovata Benn. ethyl acetate fraction extract affected the concentration of SOD, $\mathrm{MDA}$, and the expression of $\mathrm{Cu}, \mathrm{Zn} \mathrm{SOD}$ of uterus tissue cells postpartum. Allegedly, the bioactive content in the plant extracts with antioxidant efficacy in their dosages determines the activity of SOD, MDA, and the expression of $\mathrm{Cu}, \mathrm{Zn}$ SOD. Pelawan extract dosages stimulate the physiological repair of cells in the uterine tissue of the mother during the postpartum period.

\section{CONFLICT OF INTEREST}

Wasmen Manalu serves as an editor of the Tropical Animal Science Journal, but has no role in the decision to publish this article. The research about superoxide dismutase enzyme activity in rat uterus postpartum due to administration of extract pelawan (T. obotava Benn.) by the authors, there was no potential conflict of interest.

\section{ACKNOWLEDGEMENT}

This research has been supported by BUDI-DN, LPDP, RISTEK DIKTI, the Republic of Indonesia. 


\section{REFERENCES}

Adyttia, A., E. K. Untari, \& S. Wahdaningsih. 2016. Efek ekstrak etanol daun Premna cordifolia terhadap Malondialdehida tikus yang dipapar asap rokok. Pharmaceutical Sciences and Research 1:104-115. https://doi.org/10.7454/psr.v1i2.3302

Blesson, C. S., B. Masironi, \& L. Sahlin. 2012. Effect of selective estrogen receptor agonist on estrogen receptor expression in the uterus of ovariectomized rats. Molecular and Integrative Physiology 2:35-43. https://doi.org/10.4236/ ojmip.2012.22006

Dreger, H., K. Westphal, N. Wilck, G. Baumann, V. Stangl, K. Stangl, \& S. Meiners. 2010. Protection of vascular cells from oxidative stress by proteasome inhibition depends on Nrf2. Cardiovasc. Res. 85:395-403. https://doi.org/10.1093/ cvr/cvp279

Desnita, R., S. Luliana, D. S. Anastasia, \& M. A. Yuswar. 2018. Antiinflammatory activity patch ethanol extract of leaf Katuk (Sauropus androgynous L.Merr). Indonesian Journal of Pharmaceutical Sciences 16:1-5. https://doi.org/10.35814/ jifi.v16i1.493

Flowers, B., T. C. Cantley, M. J. Martin, \& B. N. Day. 1991. Episodic secretion of gonadotrophins and ovarian steroids in jugular and utero-ovarian vein plasma during the follicular phase of the oestrus cycle in gilts. J. Reprod. Fert. 91:101-112. https://doi.org/10.1530/jrf.0.0910101

Griess, B., E. Tom, F. Domann, \& M. Fitzgerald. 2017. Extracellular Superoxide Dismutase and its role in cancer. Free Radic. Biol. Med. 112:464-479. https://doi. org/10.1016/j.freeradbiomed.2017.08.013

Gumus, R. , N. Ercan, \& H. Imik. 2017. The Effect of thyme essential oil (Thymus vulgaris) added to quail diets on performance, some blood parameters, and the antioxidative metabolism of the serum and liver tissues. Rev. Bras. Cien.c Avic. 19:297-340. https://doi. org/10.1590/1806-9061-2016-0403

Hayashi, S., N. K. Hajiro, Y. Makino, H. Equchi, J. Yodoi, \& H. Tanaka. 1997. Functional modulation of estrogen receptor by redox state concerning thioredoxin as a mediator. Nucleic Acids Res. 25:4035-4040. https://doi.org/10.1093/ nar/25.20.4035

Han, J., J. S. Lee, J. C. Park, A. Hagiwara, K. W. Lee, \& J. S. Lee. 2020. Effects of temperature changes on life parameters, oxidative stress, and antioxidant defense system in the monogonont marine rotifer Brachionus plicatilis. Marine Pollution Bulletin 155:1-10. https://doi.org/10.1016/j. marpolbul.2020.111062

Ihsan, Yusfiati, \& Titrawani. 2016. Efek ekstrak etanol daun pelawan (Tristaniopsis obovata R.Br.) terhadap struktur uterus tikus putih (Rattus norvegicus Berkenhout, 1769) betina galur wistar setelah melahirkan. Jurnal Riau Biologia 1: 173-179.

Jefferson, W. N., H. B. Patisaul, \& C. J. Williams. 2012. Reproductive consequences of developmental phytoestrogen exposure. Reproduction 143:247-260. https://doi. org/10.1530/REP-11-0369

Kiracofe, G. H. 1980. Uterine involution: its role in regulating postpartum intervals. J. Anim. Sci. 51 (suppl. 2):16-28.

Kostelac, D., G. Rechkemmer, \& K. Briviba. 2003. Phytoestrogens modulate binding response of estrogen receptors $\mathrm{r}$ and $\hat{\mathrm{a}}$ to the estrogen response element. J. Agric. Food Chem. 51:7632-7635. https://doi.org/10.1021/ jf034427b

Kusunoki, T., H. Shiraishi, \& K. Murata. 2006. The role of estrogen and $\mathrm{Cu}, \mathrm{Zn} \mathrm{SOD}$ on histological changes after menopause in female rat parotid. Auris Nasus Larynx 33:47-51. https://doi.org/10.1016/j.anl.2005.07.010

Kasote, D. M., S. S. Katyare, M. V. Hegde, \& H. Bae. 2015. Significance of antioxidant potential of the plant and its relevance to therapeutic applications. Int. J. Biol. Sci. 11:982-99. https://doi.org/10.7150/ijbs.12096

Moura, D. J., M. F. Richter, J. M. Boeira, J. A. P. Henriques, \& J. Saffi. 2007. Antioxidant properties of b-carboline alkaloids are related to their antimutagenic and antigenotoxic activities. Mutagenesis. 22:293-302. https://doi.org/10.1093/ mutage/gem016

Oktari, T., Fitmawati, \& N. Safiyanti. 2014. Identifikasi dan uji fitokimia ekstrak alami tanaman antiurolithiasis. JOM FMIPA 1:10-14.

Pamela, M., S. Gagliardi, E. Cova, \& C. Cereda. 2011. SOD1 transcriptional and posttranscriptional regulation and its potential implications in ALS. Neurol. Res. Int. 2011:1-9. https://doi.org/10.1155/2011/458427

Parwata, I. M. O. A., I. B. P. Manuaba, I. W. P. Sutirtayasa, \& I. W. Wita. 2016. Gaharu leaf water extract reduce MDA and8-OhdG levels and increase activities SOD and catalase in wistar rats provided maximum physical activity. Bali Med. J. 5:434-436. https://doi.org/10.15562/bmj.v5i3.297

Quzwain, F. \& B. H. Suryawati. 2017. Hubungan antara imunoekspresi ER- $\alpha$, ER- $\beta$, dan PR dengan gradasipada tumor filodes payudara. Jurnal Kedokteran Brawijaya 29:238-243.

Qu, C. P., Z. R. Xu, G. J. Liu, C. Liu, Y. Li, Z. G. Wei, \& G. F. Liu. 2010. Differential expression of Copper-Zinc Superoxide Dismutase gene of Polygonum sibiricum leaves, stems and underground stems, subjected to high-salt stress. Int. J. Mol. Sci. 11:5234-5245. https://doi.org/10.3390/ ijms11125234

Saraswathi, C.D., S. K. Gupta, \& S. Sreemantula. 2012. Protective effect of Symplocos racemosa bark on cold restraint stress-induced reproductive changes in female rats. J. Nat. Prod. 5:251-258.

Sharma, P., A. B. Jha, R. S. Dubey, \& M. Pessarakli. 2012. Reactive oxygen species, oxidative damage, and antioxidative defense mechanism in plants under stressful conditions. J. Bot. 2012:1-26. https://doi.org/10.1155/2012/217037

Sartika, D., Fitmawati, \& Yusfiati. 2013. Uji in vitro tanaman potensial antiurolithiasis. JOM FMIPA 1:1-5.

Sheng, Y., I. A. Abreu, \& D. E. Cabelli. 2014. Superoxide dismutase and superoxide reductase. Chem. Rev. 114:9183854. https://doi.org/10.1021/cr4005296

Sugino, N., A. Karube-Harada, S. Kashida, S. Takiguchi, \& H. Kato. 2002. Differential regulation of copper-zinc superoxide dismutase and manganese superoxide dismutase by progesterone withdrawal in human endometrial stromal cells. Mol. Hum. Reprod. 8:68-74. https://doi.org/10.1093/ molehr/8.1.68

Tse, S. Y., I. T. Mak, \& B. F. Dickens. 1991. Antioxidative properties of Harmane and $\alpha$-carboline alkaloids. Biochem. Pharmacol. 42:459-464. https://doi. org/10.1016/0006-2952(91)90305-O

Todorovic, A., S. Peji'c, L. Gavrilovi'c, I. Pavlovi'c , V. Stojiljkovi'c, N. Popovi'c, \& S. B. Pajovi'. 2019. Expression of antioxidant enzymes in patients with uterine polyp, myoma, hyperplasia, and adenocarcinoma. Antioxidants 8:97. https://doi.org/10.3390/antiox8040097

Uchewa, O. \& J. O. Ezugworie. 2018. The efficacy of herbal products as an antioxidant in cushioning the effects of short-term exposure of female rats to the low dose of environmental toxicity. Pharm. Bioprocess. 6:143-153.

Unfer, T. C., L. H. Maurer, D. M. Kemerich, C. G. Figueiredo, M. M. F. Duarte, D.P. Gelain, J. C. F. Moreira, \& T. Emanuelli. 2013. Non genomic, direct modulatory effect of $17 \mathrm{~b}$-estradiol, progesteron, and their synthetic derivatives on the activity of human erythrocyte $\mathrm{Cu} / \mathrm{Zn}$ superoxide dismutase. Free Radic. Res. 47:219-232. https://doi.org/10. 3109/10715762.2012.762770

Unfer, T.C., C.G. Fiqueiredo, M. M. Zanchi, L. H. Maurer, D. M. Kemerich, M. M. F. Duarte, C. K. Konopka, \& T. 
Emanuelli. 2014. Estrogen plus progestin increase superoxide dismutase and total antioxidant capacity in postmenopausal women. Climateric 17:1-10.

Viggiani, M. T., L. Polimeno L, A. Di Leo, \& M. Barone. 2019. Phytoestrogens: dietary intake, bioavailability, and protective mechanisms against colorectal neoproliferative lesions. Nutrients 11:1-12. https://doi.org/10.3390/ nu11081709

Wettermann, R. P. 1980. Postpartum endocrine function of cattle, sheep and swine. J. Anim. Sci. 51 (suppl. 2):2-15.

Widowati, H., H. Sujuti, \& K. Mintaroem. 2018. Effect of peroral cypermethrin exposure on serum $17 \beta$ estradiol and uterine
Malondialdehyde (MDA) levels in female Wistar strain rats (Rattus novergicus). Majalah Obstetri \& Ginekologi 26:20-25. https://doi.org/10.20473/mog.V26I12018.20-25

Wresdiyati, T., I. K. M. Adnyane, S. A. Prabandari, \& Sofiawati. 2019. Profil imunohistokimia antioksidan Copper, ZincSuperoxide Dismutase ( $\mathrm{Cu}, \mathrm{Zn}$ SOD) pada ginjal tikus perinatal dan neonatal. Biota 9:163-170.

Yusfiati, W. Manalu, T. Wresdiyati, \& H. Maheshwari. 2020. Antioxidant activity of pelawan (Tristaniopsis obovata Benn.) Leaf extracts by the use of DPPH method. Res. J. Pharm. Biol. Chem. Sci. 11:134-141. 